\title{
PENGARUH KECERDASAN EMOSIONAL, MOTIVASI KERJA, DAN SIKAP KERJA TERHADAP KINERJA KARYAWAN PADA PT ITHACA RESOURCES
}

\author{
Mochammad Subagio \\ Fakultas Ekonomi Universitas Suryadarma Jakarta \\ Email: bagiolab83@yahoo.co.id
}

\begin{abstract}
The obyective of this research is to study the effect of emotional intelligence, job attitudes, work motivation on performance employee. The research was conducted at the Ithaca Resources Company Jakarta. It was using causal study method. The samples of this research were 90 personel of the Ithaca Resources Company that selected randomly. The research findings are: (1) there is a direct effect of emotional intelligence on job attitudes (2) there is a direct effect of work motivation on job attitudes (3) there is a direct effect of emotional intelligence on performance employee; (4) there is a direct effect of work motivation on performance employee; (5) there is a direct effect of job attitudes on performance employee; Based on these findings, it could be concluded that performance employee is affected by emotional intelligence, work motivation and job attitudes. And the emotional intelligence is the most dominant that effect the performance employee. On the other word, the higher emotional intelligence effects more directly on the performance employee Therefore, the emotional intelligence, work motivation and job attitudes should be taken into consideration in determining performance employee at ithaca resouces company of jakarta
\end{abstract}

Keywords: Performance employee, emotional intelligence, work motivation, job attitudes

\begin{abstract}
Abstrak: Tujuan dari penelitian ini adalah untuk mempelajari pengaruh kecerdasan emosional, sikap kerja, motivasi kerja pada karyawan kinerja. Penelitian ini dilakukan di Ithaca Resources Company Jakarta. Itu menggunakan metode studi kausal. Sampel penelitian ini adalah 90 personel dari Ithaca Resources Perusahaan yang dipilih secara acak. Temuan penelitian ini adalah: (1) ada pengaruh langsung kecerdasan emosional terhadap sikap kerja (2) ada pengaruh langsung motivasi kerja terhadap sikap kerja (3) ada pengaruh langsung kecerdasan emosional pada karyawan kinerja; (4) ada pengaruh langsung motivasi kerja pada karyawan kinerja; (5) ada pengaruh langsung dari sikap kerja terhadap karyawan kinerja; Berdasarkan temuan ini, dapat disimpulkan bahwa karyawan kinerja dipengaruhi oleh kecerdasan emosional, motivasi kerja dan sikap kerja. Dan kecerdasan emosional adalah yang paling dominan yang berpengaruh karyawan kinerja. Pada kata lain, efek kecerdasan emosional tinggi lebih langsung pada karyawan kinerja Oleh karena itu, kecerdasan emosional, motivasi kerja dan sikap kerja yang harus dipertimbangkan dalam menentukan karyawan kinerja di resouces ithaca perusahaan Jakarta.
\end{abstract}

Kata kunci: Kinerja karyawan, kecerdasan emosional, motivasi kerja, sikap kerja 


\section{PENDAHULUAN}

Menjelang abad ke 21, para pemimpin ASEAN dan Dunia melakukan pertemuan untuk membahas perdagangan bebas, akhirnya dari hasil pertemuan tersebut telah disepakati perdagangan bebas dimulai tingkat Asean pada tahun 2008. Selanjutnya pada tahun 2010 mulai diberlakukan perdagangan bebas di seluruh wilayah Asia Pasifik mengakibatkan banyak terjadinya perpindahan tenaga kerja asing dari negara maju menuju ke negara berkembang termaksud negara Indonesia. Hal ini bagi perusahaan merupakan tantangan untuk menyiapkan tenaga kerja yang berkualitas dalam menghadapi perekonomian global agar mendapatkan keuntungan secara maksimal sekaligus mengurangi kerugian dari persaingan global.

Dengan dimulai berlakunya perdagangan bebas seluruh Asia Pasifik banyak membawa pesaing ataupun tenaga ahli yang berkompeten dibidangnya dari pelbagai mancanegara memasuki pasar domestik dengan kandungan pengetahuan tingkat dunia. Negara Indonesia adalah termaksud salah satu Negara yang jumlah penduduknya terbesar di dunia dan mempunyai wilayah potensial di kawasan Asia Tenggara, menjadikan Indonesia sebagai ladang bisnis yang menjanjikan sebagai sasaran pasar berbagai produk dan jasa. Sehingga diperkirakan Indonesia akan dibanjiri oleh banyak produk dan pekerja profesional dari luar negeri.

Dalam era globalisasi ini diharapkan bagi perusahaan swasta nasional harus mampu menghadapi persaingan. Hal tersebut harus didukung oleh tenaga kerja yang profesional sesuai dengan standar kerja pesaingnya dan kalau bisa harus lebih unggul dari pesaingnya. Secara konsep banyak pendefinisian tentang kinerja disesuaikan dengan tujuan masing masing, ada yang diarahkan pada prestasi, ada nada juga yang diarahkan atas hasil interaksi. Hal tersebut merupakan salah satu faktor saja sebagai penentu kinerja karyawan, sebenarnya kinerja ditentukan oleh banyak faktor dan tidak berdiri sendiri. Dalam organisasi, apabila manajemen dapat menentukan faktor-faktor apa saja yang dapat mempengaruhi kinerja (performance) tersebut, maka manajemen perusahaan dapat mengambil berbagai langkah yang diperlukan agar dapt meningkatkan kinerja yang bisa sesuai dengan harapan perusahaan. Dalam penelitian ini kecerdasan emosional, sikap kerja, motivasi kerja diharapkan punya peran dalam meningkatkat kinerja karyawan dalam perusahaan.

Seseorang yang mempunyai kecerdasan emosional yang tinggi mempunyai kemampuan untuk mengelola perasaannya antara lain dapat memotivasi dirinya sendiri dan orang lain, tegar menghadapi frustasi, sanggup mengatasi dorongan-dorongan primitif dan menunda kepuasan sesaat, mengatur suasana hati yang aktif dan mampu berempati dan mampu memberikan pelayanan yang lebih baik.

Sedangkan motivasi kerja, adalah agar setiap karyawan mempunyai dorongan melakukan suatu kegiatan untuk mencapai tujuan. Motivasi merupakan keadaan pribadi dalam seseorang yang mendorong keinginan individu untuk melakukan kegiatan tertentu guna mencapai tujuan dan manfaat motivasi menciptkan gairah kerja untuk meningkatkan kinerja. Sikap kerja terkait dengan perasaan suka atau tidak suka dalam menangkap obyek, orang, situasi termasuk kebijakan sosial kikap kerja turut mempengaruhi kinerja dalam lingkungan kerjanya. Sikap kerja merupakan kesiapan mental dan fisik untuk bekerja dengan cara tertentu yang dapat dilakukan dalam kecenderungan tingkah laku karyawan dalam menjalankan aktivitasnya sebagai upaya memperkaya kecakapan dan kelangsungan hidup. 
Dalam penelitian ini Kinerja, Sikap Kerja, Motivasi Kerja dan kecerdasan emosional masing-masing dijadikan sebagai variabel penelitian. Sejalan dengan uraian diatas, PT Ithaca Resources Jakarta dipilih sebagai tempat dilakukan penelitain untuk menguji hubungan diantara variabel tersebut. PT Ithaca Resources adalah perusahaan yang bergerak di bidang pertambangan batubara yang merupakan salah satu perusahaan swasta nasional yang menjadi lokomotif kemajuan ekonomi di Indonesian khususnya disektor tambang batutara.

Berdasarkan latar belakang yang telah disampaikan diatas, terdapat indentifikasi masalah yang dapat mempengaruhi kinerja (a) Kecerdasan emosional karyawan yang belum maksimal, akan berpengaruh terhadap kinerja karyawan. Kecerdasan emosional karyawan yang rendah tersebut dampaknya karyawan tidak mampu berkinerja secara maksimal, sehingga diprediksi adanya pengaruh kecerdasan emosional terhadap kinerja karyawan; (b) Motivasi kerja karyawan yang belum mendukung. Apabila karyawan mojanya rendah maka akan mengakibatkan kinerja karyawan juga rendah, sehingga diprediksi adanya pengaruh motivasi kerja terhadap kinerja karyawan; (c) Sikap Kerja Karyawan yang masih buruk, Sikap kerja sebagai cermin dari profeionalitas akan berdampak pada hasil kerja. Sehingga buruknya sikap kerja aakan berdampak pada kinerja karyawan, sehingga diprediksi adanya pengaruh sikap kerja terhadap kinerja karyawan; (d) Kultur kerja karyawan yang belum optimal. Budaya kerja akan menjadi refleksi dari kecerdasan emosional karyawan, sikap kerja, motivasi kerja yang berdampak pada kinerja karyawan, hal tersebut dapat diprediksi adanya pengaruh budaya kerja terhadap kecerdasan emosional, sikap kerja dan motivasi kerja karyawan; (e) Sistem reword yang belum mendukung, sehingga kurang memberikan semangat kerja yang berdampak pada sikap dan motivasi kerja karyawan, oleh sebab itu diprediksi adanya pengaruh system reword terhadap sikap dan motivasi kerja karyawan; (f) Sistem pembinaan karyawan yang belum maksimal, sehingga karyawan kurang memiliki sikap dan motivasi kerja yang maksimal, sehingga dampaknya diprediksi sistem pembinaan berpengaruh terhadap sikap dan motivasi kerja.

Berdasarkan hasil identifikasi permasalahan diatas, maka penelitian ini akan dibatasi pada variabel yang diduga berpengaruh kuat dan langsung terhadap kinerja karyawan. Dalam batasan masalah penelitian ini, variabel independen yang berpengaruh langsung terhadap variabel kinerja dibatasi pada kecerdasan emosional, motivasi kerja dan sikap kerja, karena diduga ketiga variabel tersebut sangat dominan pengaruhnya terhadap kinerja karyawan di tempat penelitian

Berdasarkan penjelasan uraian di atas, maka masalah dalam penelitian ini dapat dirumuskan sebagai berikut: (1) Apakah kecerdasan emosional berpengaruh langsung terhadap kinerja karyawan, (2) Apakah motivasi kerja berpengaruh langsung terhadap kinerja karyawan, (3) Apakah sikap kerja berpengaruh langsung terhadap kinerja karyawan, (4) Apakah kecerdasan emosional berpengar terhadap sikap kerja, (5) Apakah motivasi kerja berpengaruh langsung terhadap sikap kerja.

\section{KAJIAN TEORI}

Kinerja. Kinerja adalah output dari pengaruh input. Kinerja memiliki pengertian sebagai suatu hasil atau efek samping atas usaha yang telah dilakukan. Sering orang menggunakan kata kinerja atau prestasi kerja untuk suatu pekerjaan yang telah berhasil dilaksanakan, 
baik prestasi yang diraih secara individu seperti kinerja karyawan, maupun secara berkelompok seperti kinerja organisasi perusahaan.

Kinerja mengacu pada prestasi karyawan yang diukur berdasarkan standar atau kriteria yang ditetapkan perusahan. Menurut Moh As'ad (2003) pengertian kinerja atau prestasi kerja sebagai kesuksesan seseorang di dalam melaksanakan suatu pekerjaan, demikian pula menurut Lawler and Poter juga yang dikutip oleh As'ad, menyatakan bahwa kinerja adalah "succesfull role achievement" yang diperoleh seseorang dari perbuatan-perbuatannya.

Menurut Bacal (2001), standards (performance): a set of expectation. Applicable to a specific employee, outlinting what the employee is expected to achieve. Ideally standards of performance are measurable in an obyective way and focus on observable behavior or result.

Menurut Guritno dan Waridin (2005) kinerja merupakan perbandingan hasil kerja yang dicapai oleh karyawan dengan standar yang telah ditentukan. Dengan demikian kinerja sebagai hasil kerja yang dicapai oleh individu yang disesuaikan dengan peran atau tugas individu tersebut dalam suatu perusahaan pada suatu periode waktu tertentu, yang dihubungkan dengan suatu ukuran nilai atau standar tertentu dari perusahaan dimana individu tersebut bekerja, sehingga kinerja merupakan perbandingan hasil kerja yang dicapai oleh karyawan dengan standar yang telah ditentukan.

Secara individu Singh dan Billingsley (2000) mengatakan bahwa kinerja merupakan hasil pekerjaan yang dilakukan oleh pegawai sesuai dengan tujuan yang ingin dicapai dalam pekerjaan yang dilakukan. Pandangan Colquitt, LePine dan Wesson (2008), bahwa kinerja sebagai "the value of the set of employee behaviors that contribute, either possitively or negatively, to organizational goal accomplishment" (nilai dari seperangkat perilaku karyawan yang berkontribusi, baik secara positif atau negatif terhadap pemenuhan tujuan organisasi). Kinerja juga menurut Colquitt, LePine dan Wesson (2008) ditentukan oleh tiga faktor yaitu: 1) kinerja tugas (task performance), dan 2) perilaku kesukarelaan (citizenship behavior) sebagai kontribusi perilaku positif dan 3) perilaku produktif tandingan (counter productive behavior) sebagai kontribusi negatif. Kinerja tugas dipengaruhi oleh faktor rutinitas dan adaptasi, perilaku kesukarelaan dipengaruhi oleh faktor interpersonal, dan faktor organisasional, perilaku produktif tandingan dipengaruhi oleh faktor deviasi politik dan faktor agresi personal

Mengarah pada kinerja organisasi yang dipengaruhi oleh berbagai faktor. Amstrong dan Baron (2008) mengemukakan bahwa kinerja organisasi dipengaruhi oleh empat faktor, yaitu faktor personal, meliputi keterampilan individu, kompetensi, motivasi, bimbingan yang diberikan; faktor sistem perkerjaan dan fasilitas yang diberikan oleh organisasi; dan faktor situasional meliputi perubahan dan penekanan dari faktor internal dan eksternal

Faktor kinerja organisasi menurut Locke dan Latham, ditentukan oleh kemampuan personal (ability), komitmen, umpan balik (feed back), kompleksitas tugas (task convexity), tantangan (challenge), tujuan (goal), kondisi yang menghambat (situasional constrant), kekuatan organisasi ( organization afficacy), arahan (direction) pimpinan, usaha (effort), daya tahan, ketekunan (persistance) anggora, strategi khusus dalam melaksanakan kegiatan (activity spesific strategis

Menurut Amstrong (2005), performance means both behaviours and results. Behaviours emanate from the perfomer and transform performance from 
abstraction to action. Not just the instrumens for result, behaviours are also otcomes in their own riht the pduct of mental and physical effort applied to taskand can be judged apart from result.

Sikap Kerja. Sikap kerja terkait dengan anggapan dasar tentang kerja dengan karyawannya. Dalam organisasi perusahaan tergantung dari sudut mana seorang karyawan memandang tentang pekerjaannya. Menurut Von Magnis dalam Anoraga (2002), yang dimaksud dengan pekerjaan adalah "kegiatan yang direncanakan".Jadi pekerjaan itu memerlukan pemikiran yang khusus dan dilaksanakan dengan sungguh-sungguh untuk mencapai suatu hasil, baik berupa benda, karya, tenaga maupun sebagai pelayanan terhadap masyarakat, termasuk dirinya sendiri. Dengan demikian bekerja mengandung arti melaksanakan suatu tugas yang diakhiri dengan buah karya yang dapat dinikmati oleh manusia yang bersangkutan. Dalam pengertian yang paling sederhana, pekerjaan adalah "Sesuatu yang dilakukan seseorang untuk dapat memperoleh imbalan, baik berupa uang atau balas jasa lain“. Seperti yang dikemukakan oleh Smith, yang juga dalam Anoraga (2002) mengenai tujuan dari kerja adalah "untuk hidup“. Jadi mereka yang melakukan kegiatan fisik maupun kegiatan otak dengan mendapat imbalan sarana kebutuhan untuk hidup berarti bekerja.

Sikap karyawan bekerja dalam organisasi perusahaan sangat menentukan berhasil atau tidaknya kehidupan pribadi atau karir. Karena sikap atau gaya kerja yang baik merupakan kebutuhan dalam meniti karir, sedangkan sistim kerja yang baik merupakan kebutuhan bagi organisasi perusahaannya. Hal ini sesuai dengan pendapat Calhoun dan Acocella (2007) dalam buku Psychology of Ajustment and Human Relationship yaitu sikap kerja dibutuhkan suatu individu untuk menata pola atau ritme kehidupan pribadi, sebagai dasar harga diri seseorang dalam membangun kompetensi dirinya, membangun kehidupan sosial dan memberikan kehidupan sosial serta memberikan identitas atau status bagi dirinya, dengan demikian sikap kerja merupakan mental psikologi seseorang dalam bekerja. Pengertian sikap juga di kemukakan oleh New com dalam Walgito (2001) adalah sebagai berikut:

"From a cognitive point of view, an attitude represents an organization of valanced cognitions from of motivational point of readiness for motive arousel " Di sini New com menghubungkan antara sikap dengan motif, sikap merupakan kesiapan atau keadaan siap untuk tumbuhnya suatu motif. Sikap merupakan suatu keadaan yang memungkinkan timbulnya suatu perbuatan atau tingkah laku. Jadi bila seorang karyawan tidak mempunyai sikap tertentu terhadap suatu kejadian atau keadaan yang ada di luar dirinya maka karyawan tersebut tidak akan bergerak motifnya untuk sesuatu tindakan atau kegiatan kerha tertentu. Tetapi sebaliknya bila seorang karyawan mempunyai suatu sikap tertentu, maka segala sesuatu yang menyangkut masalah kegiatan kerja tersebut akan menjadi motif yang dapat menimbulkan tingkah laku kerja bagi seorang karyawan tersebut.

Menurut All Port, konsep sikap yang dikembangkan oleh Sherief (2008), sebagai kesiapan saraf (Neutral Setting) sebelum merespons, maka sikap mempunyai karakteristik sebagai berikut: a) bukan gaya tetapi kecenderungan gaya, b) kecenderungan bertindak, berfikir, berperasaan, dan berprestasi dalam menangkap obyek, nilai, situasi dan ide, c) memiliki daya pendorong, d) relatif mapan, e) mengandung aspek evaluatif, diorganisir oleh pengalaman. Menurut Pophan (2005) bahwa terdapat perbedaan antara sikap dan nilai terutama yang berhubungan dengan sentimen adalah bersifat langsung. Jadi karena sintimen merupakan curahan rasa terhadap sesuatu yang direspon, maka sikap karyawan 
terhadap organisasinya dapat dilihat dari respon positif maupun negatif yang diekspresikan dalam bekerja. Sikap terdiri dari dua komponen, Kognisi dan Affeksi. Komponen kognisi yang berhubungan dengan belief (kepercayaan atau keyakinan), ide, konsep persepsi, stereotipe, opini yang dimiliki individu mengenai sesuatu. Komponen Afeksi yang berhubungan dengan kehidupan emosional seseorang menyangkut perasaan individu terhadap objek sikap dan menyangkut masalah emosi. Komponen Kognisi yang merupakan kecenderungan bertingkah laku "kecenderungan" belum berperilaku. Interaksi antara komponen sikap: seharusnya membentuk pola sikap yang seragam ketika dihadapkan pada obejk sikap. Apabila salah satu komponen sikap tidak konsisten satu sama lain, maka akan terjadi ketidakselarasan akibat terjadi perubahan sikap.

Kecerdasan Emosional. Emosi merupakan sekumpulan interaksi yang sangat rumit di antara faktor subyektif dan obyektif yang diturunkan dari sistem syaraf atau hormonal dari manusia. Sehingga secara umum emosi mengisyaratkan bahwa perasaan yang paling dalam, nafsu, dan hasrat merupakan pedoman yang paling penting, bahwa spesies manusia berhutang amat banyak pada kekuatan emosi. Karena adanya kekuatan emosi menunjukkan keberadaan manusia. Dalam hal ini implementasi emosi mewarnai persepsi individu terhadap dirinya sendiri dan lingkungannya, emosi juga berdampak terhadap penampilan perilaku afektif seseorang karyawan. Dengan karakteristik pola adaptif tersebut seseorang dalam kehidupannya akan mempengaruhi kepribadiannya, tetapi pada prinsipnya emosi dapat menambahkan kesenangan hidup dan dapat memotivasi kegiatan dalam meningkatkan proses penyesuaian terhadap diri dan lingkungan, oleh sebab itu intensitas dan kedalaman emosi sangat berpengaruh terhadap kepribadian seseorang, termasuk karyawan.

Ditinjau dari peranya menurut Plutchik (2004), emosi dapat: (1) membangkitkan pengalaman afektif seperti membangkitkan perasaan, (2) membangkitkan proses kognitif seperti dampak persepsi yang relevan dengan emosionalnya, (3) mengaktifkan penyesuaian diri secara lebih luas terhadap kondisi yang dapat dibangkitkan, (4) seringkali berpengaruh terhadap perilaku seperti ekspresif, pencapaian tujuan dan dalam melakukan adaptasi. Suatu perasaan subyektif sering diidentifikasikan sebagai emosi secara relatif, hal tersebut merupakan perkembangan yang seharusnya tidak digunakan sebagai kriteria utama terhadap keadaan emosi seseorang. Karena emosi merupakan hal yang rumit, interaktif dan adaptif maka bentuk ekspresi sangat bervariatif dan masing-masing orang dalam menggunakan dan mengembangkannya sesuai dengan kondisi tertentu.

Emosi mewarnai persepsi individu terhadap diri sendiri dan lingkungannya, emosi juga berdampak terhadap penampilan perilaku seseorang. Dengan karakteristik pola adaptif tersebut seseorang dalam kehidupannya akan mempengaruhi kepribadiannya, tetapi pada prinsipnya emosi dapat menambahkan kesenangan hidup dan dapat memotivasi kegiatan dalam meningkatkan proses penyesuaian terhadap diri dan lingkungan, oleh sebab itu intensitas dan kedalaman emosi sangat berpengaruh terhadap kepribadian seseorang.

Pandangan lain tentang emosi sering diasosiasikan dengan perilaku yang bertujuan. Emosi didefinisikan sebagai perasaan atau feeling, secara subyektif dapat dilihat dari: pengalaman afektif, senang atau tidak senang, secara primer dapat dilihat dari perilaku: marah, ketakutan, kebahagiaan, kesedihan, kejutan dan kebencian. Jadi konsep emosi sering digambarkan dengan perilaku ekspresif dan respons fisiologis ataupun suatu proses 
yang dipengaruhi oleh potensi motivasi yang disadari, atau dengan kata lain emosi merupakan mekanisme hasil keluaran yang membawa informasi tentang sistem motivasi

Kecerdasan emosional adalah bagian dari kecerdasan sosial yang melibatkan kemampuan untuk memonitor emosi diri sendiri dan perasaan orang lain, untuk membedakan antara mereka, dan menggunakan informasi untuk memandu seseorang berpikir dan tindakan. Seseorang yang mengenal emosi diri sendiri dan mampu dengan baik membaca emosi orang lain dapat menjadi lebih efektif dalam pekerjaan. Lebih lanjut dikatakan bahwa kecerdasan emosional terdiri dari lima dimensi, yaitu: (1) kesadaran diri sendiri (self-awareness), yaitu menyadari apa yang dirasakan, (2) pengelolaan diri sendiri (self-management), yaitu kemampuan pengelolaan emosi diri sendiri, (3) empati (empathy), yaitu kemampuan untuk merasakan bagaimana perasaan orang lain, (4) kecakapan sosial (social skills), yaitu kemampuan untuk menangani emosi orang lain. Selain itu, orang-orang yang motivasinya tinggi dalam pekerjaan adalah orang-orang yang berkometmen secara emosional. Dapat dikatakan kecerdasan emosional berpengarung terhadap motivasi kerja.

Menurut Robbins dan Judge (2009), menyatakan bahwa dalam studi yang menyoroti tentang emosi terhadap motivasi menyarankan terhadap organisasi untuk mendorong emosi yang positif dalam pekerjaan berkemungkinan besar akan lebih memiliki tenaga kerja yang termotivasi. Dengan demikian kecerdasan emosional berpengaruh terhadap motivasi kerja.

Menurut Luthans (2008),"Emotional intelligence is a person's ability to (1) be selfaware (to recoqnize her own emotions when she experiences them), (2) detect emotions in onther, and (3) manage emotional cues and information". Artinya, kecerdasan emosional adalah kemampuan seseorang untuk: (1) sadar diri, mengenali emosi diri sendiri, (2) mendeteksi emosi orang lain, (3) mengelola emosi dan informasi, dalam hubungannya dengan orang lain. Jika seseorang mampu mengetahui emosi diri sendiri dan membaca emosi orang lain, maka dengan mudah mengetahui bahwa mereka sedang marah dan bagaimana mengekspresinya. Sehingga akan lebih efektif dalam bekerja.

Menurut Kinichi dan Kreitner (2008), "Emotional intelligence is the ability to manage oneself and one's relationships in mature and constructive ways". Antinya, Kecerdasan emosional adalah kemampuan untuk mengelola diri sendiri dan hubungan dengan seseorang secara konstruktif. Kecerdasan emosional memiliki empat komponen kunci: (1) kesadaran diri (self awareness), (2) manajemen diri (self management), (3) kesadaran sosial (social awareness), dan (4) manajemen hubungan (relationship management). Dapat dikelompokan bahwa kesadaran diri dan manajemen diri merupakan kompetensi pribadi; sedangkan kesadaran sosial dan manajemen hubungan merupakan kompetensi sosial.

Menurut Cooper dan Sawaf (2001), kecerdasan emosional adalah merupakan faktor yang menentukan sukses dalam karier dan organisasi, termasuk: pembuatan keputusan, kepemimpinan, terobosan teknis dan strategis, komunikasi yang terbuka dan jujur, team work dan hubungan saling mempercayai, loyalitas konsumen, dan kreativitas dan inovasi. Lebih lanjut Cooper dan Sawaf (2001) mengatakan bahwa: kecerdasan emosional adalah kemampuan merasakan, memahami, dan secara efektif menerapkan daya dan kepekaan emosi sebagai sumber energi, informasi, koneksi, dan pengaruh yang manusiawi.

Motivasi Kerja. Motivasi adalah proses psikologi dan merupakan salah satu unsur pokok perilaku seseorang termasuk karyawan. Thoha (2005) mengatakan bahwa motivasi adalah 
dorongan agar seseorang melakukan suatu kegiatan untuk mencapai tujuan. Sedangkan menurut Hampton (2006), motivasi karyawan adalah perlakuan seseorang bertindak karena tertarik akan kebutuhannya. Dengan demikian implikasi motivasi adalah sebagai kegiatan yang terdorong oleh kebutuhan yang ingin diraih. Motivasi tersebut memiliki kekuatan laten yang besar sehingga sangat bermanfaat bagi setiap orang untuk memenuhi keinginan. Dengan motivasi potensi-potensi yang ada dalam diri seseorang mampu diaktualisasikan, yang menjadi pertanyaan adalah bagaimana konsistensi seseorang dalam mewujudkan motivasi menjadi kenyataan.

Kemudian Duncan mengemukakan dalam perspektif manajerial yang dikutip oleh Wahjosumidjo (1999) “ motivation refers to any concious attempt to influence behavior toward the accomplishment of organizational goal" secara bebas diartikan bahwa motivasi adalah suatu usaha sadar untuk mencoba mempengaruhi perilaku seseorang agar dapat mencapai tujuan organisasi. Pendapat-pendapat di atas dapat disimpulkan bahwa motivasi karyawan adalah suatu kesadaran dan ketertarikan karyawan dalam melakukan kegiatan kerja atas dorongan dan pengaruh perilaku kebutuhan untuk mencapai keberhasilan pekerjaan dalam organisasi perusahaannya.

Teori motivasi yang paling dikenal adalah hierarki kebutuhan (hierarchy of needs) yang diungkapkan Abraham Maslow (1985). Hipotesisnya mengatakan bahwa di dalam diri semua manusia terdapat lima jenjang kebutuhan, yaitu Physiological Needs, Safety and Security, Social Needs, Esteem Needs, Self Actualization.

Penjelasan masing-masing komponen motivasi menurut Abraham Maslow (1985) sebagai berikut: (1) Physiological Needs (kebutuhan fisikologi) adalah kebutuhan paling dasar, antara lain rasa lapar, haus, pakaian, perumahan, seks, dan kebutuhan jasmani lain, (2) Safety and Security (keamanan dan keselamatan) antara lain keselamatan dan perlindungan terhadap kerugian fisik dan emosional, (3) Social Needs (kebutuhan sosial) mencakup kasih sayang, rasa memiliki, diterima dengan baik, dan persahabatan, (4) Esteem Need (kebutuhan akan penghargaan) mencakup faktor penghormatan diri, seperti harga diri, otonomi, dan prestasi; serta faktor penghormatan dari luar seperti status, pengakuan dan perhatian, (5) Self Actualization (kebutuhan aktualisasi diri) yaitu dorongan untuk menjadi sesuatu sesuai ambisinya. Hal ini mencakup pertumbuhan, pencapaian potensi, dan pemenuhan kebutuhan diri. Begitu kebutuhan tersebut terpenuhi secara substansial, kebutuhan berikutnya akan menjadi dominan.

Dalam individu bergerak naik mengikuti anak tangga hierarki. Dari titik pandang motivasi, teori ini mengatakan bahwa meskipun tidak ada kebutuhan yang bisa dipenuhi sepenuhnya, kebutuhan tertentu yang telah dipuaskan secara substansial tidak lagi menjadi pendorong motivasi. Jadi, jika kita ingin memotivasi seseorang, menurut Maslow (1985), kita perlu memahami sedang berada di anak tangga manakah orang itu dan kita harus fokus pada pemenuhan kebutuhan di tingkat atasnya. Maslow (1985) memisahkan kelima kebutuhan itu sebagai tingkat tinggi dan rendah. Kebutuhan psikologis dan kebutuhan akan keamanan digambarkan sebagai kebutuhan tingkat rendah, sementara kebutuhan sosial, kebutuhan akan penghargaan, dan aktualisasi diri didudukkan ke dalam tingkat tinggi. Perbedaan antara kedua tingkat itu bahwa kebutuhan tingkat tinggi dipenuhi secara internal (dalam diri orang itu), sedangkan kebutuhan tingkat rendah dipenuhi secara eksternal (dengan upah, kontak serikat buruh, dan masa kerja).

Menurut Douglas McGregor yang dikutip Robbins (2008) yang mengemukakan dua pandangan tetang manusia, pada dasarnya yang satu negatif yang ditandai sebagai Teori $\mathrm{X}$ dan positif yang ditandai dengan Teori Y. Lebih lanjut dikatakan bahwa Teori X, 
diasumsikan bahwa karyawan tidak menyukai kerja, malas, tidak meyukai tanggung jawab, dan harus dipaksa agar berprestasi. Sedangkan Teori Y, diasumsikan bahwa karyawan menyukai kerja, kreatif, berusaha bertanggung jawab, dan dapat menjalankan pengarahan diri. Sehingga dapat dikatakan karyawan yang menyukai kerja, kreatif, dapat mengendalikan emosi dan bertanggung jawab maka akan berpikir secara rasional sehingga dapat mengambil keputusan yang efektif.

Menurut Ferderick Herzberg, yang dikutip Robbins (2003) tentang teori dua faktor (two-factor theory) yang sering disebut teori motivasi-higiene, yaitu faktor intrinsik yang berubungan dengan kepuasan kerja, dan faktor ekstrinsik yang berhubungan dengan ketidakpuasan. Faktor-faktor intrinsik antara lain kemajuan, prestasi, pengakuan, dan tanggung jawab, sedangkan faktor-faktor ekstrinsik antara lain pengawasan, gaji, kebijakan perusahaan, dan kondisi kerja. Teori ini berkaitan dengan hubungan individu dengan pekerjaannya yang merupakan hubungan sikap seseorang terhadap pekerjaan yang dapat menentukan kesuksesan atau kegagalan individu.

Clayton Alderfer berusaha mengelola hierarki kebutuhan Maslow (2003) agar semakin dekat dengan penelitian empiris yang disebut dengan teori ERG (Existence needs, Reletedness needs, Growth needs) Clayton Alderfer (1992) berpendapat bahwa terdapat tiga kelompok kebutuhan inti: (1) kehidupan atau eksistensi (existence) yaitu tentang pemberian materiil dasar sebagai kebutuhan psikologis dan keamanan, (2) keterhubungan (relatedness) yaitu hasrat untuk memelihara hubungan baik, hubungan sosial yang menuntut terpenuhinya interaksi, (3) pertumbuhan (growth) yaitu kebutuhan penghargaan dan aktualisasi diri. Teori ERG berargumen bahwa kebutuhan tingkat lebih rendah terpuaskan menghantar ke hasrat memenuhi kebutuhan ke tingkat lebih tinggi.

Hipotesis Penelitian. Berdasarkan deskripsi teorektik dan hasil kerangka berpikir di atas, dalam penelitian ini diajukan hipotesis penelitian sebagai berikut: (1) Kecerdasan Emosional berpengaruh langsung positif terhadap Kinerja Karyawan, (2) Motivasi Kerja berpengaruh langsung positif terhadap Kinerja Karyawan, (3) Sikap Kerja berpengaruh langsung positif terhadap Kinerja Karyawan, (4) Kecerdasan Emosional berpengaruh langsung positif terhadap Sikap Kerja Karyawan, (5) Motivasi Kerja berpengaruh langsung positif terhadap Sikap Kerja Karyawan. Adapun model teoritik dapat dilihat pada gambar berikut

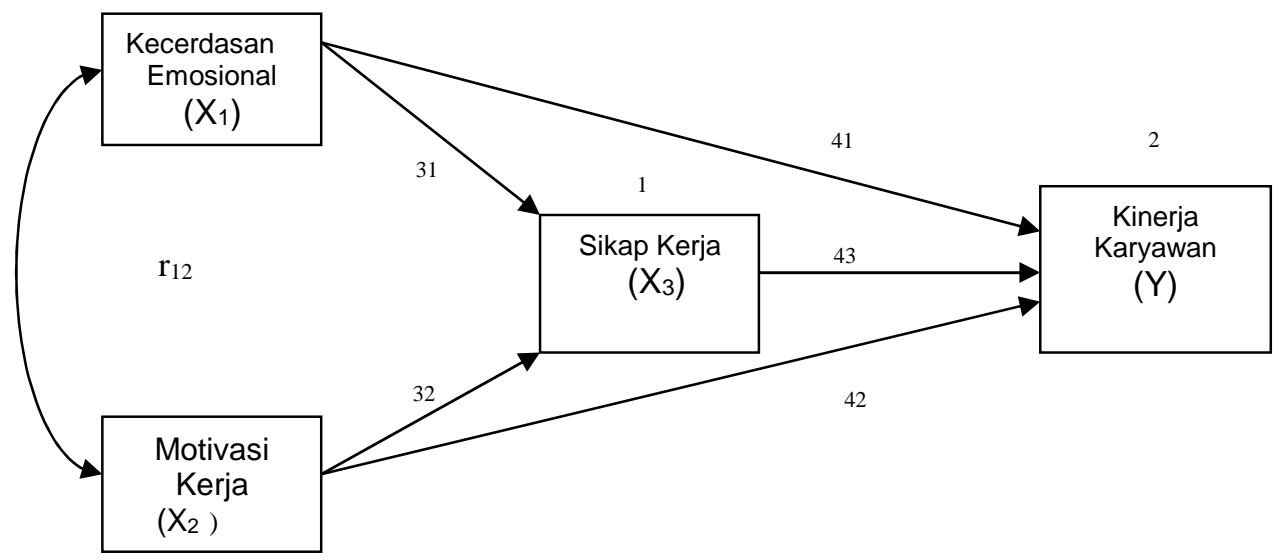

Gambar 1. Kerangka Pemikiran 
Keterangan: $\mathrm{X}_{1}=$ Kecerdasan Emosional; $\quad \mathrm{X}_{2}=$ Motivasi Kerja; $\mathrm{X}_{3}=$ Sikap Kerja; $\mathrm{Y}=$ Kinerja Karyawan; $\beta_{\mathrm{ij}}=$ Koefisien Jalur; $\varepsilon_{\mathrm{i}}=$ Variabel residu

\section{METODE}

Secara umum tujuan penelitian ini untuk mengkaji ada atau tidaknya pengaruh kecerdasan emosional, motivasi kerja, dan sikap kerja terhadap kinerja karyawan di PT Ithaca Resources Jakarta. Sedangkan secara khusus, penelitian ini untuk membuktikan: (1) Pengaruh langsung kecerdasan emosional terhadap kinerja karyawan, (2) Pengaruh langsung motivasi kerja terhadap kinerja karyawan, (3) Pengaruh langsung sikap kerja terhadap kinerja karyawan, (4) Pengaruh langsung kecerdasan emosional terhadap sikap kerja, (5) Pengaruh langsung motivasi kerja terhadap sikap kerja.

Penelitian dilakukan di PT Ithaca Resources Jakarta. Penelitian dilaksanakan selama tiga bulan, dimulai sejak proposal penelitian disetujui. Satu bulan pertama digunakan untuk mengurus izin penelitian, uji coba instrument, kalibrasi, dan penyempurnaan instrumen. Dua bulan terakhir digunakan untuk pengambilan data, analisis data, dan penulisan seminar hasil

Metode penelitian yang digunakan adalah metode lapangan (Field Research) melalui survei.sal. Sedangkan untuk menganalisis ada atau tidaknya pengaruh antara satu variabel dengan variabel yang lain menggunakan analisis jalur (path analysis). Analisis jalur ini memerlukan persyaratan adanya hubungan regresi linear yang signifikan antara setiap dua variabel. Namun untuk menghitung koefisien tiap jalur diperlukan koefisien korelasi setiap dua variabel. Oleh karena itu, untuk menyelesaikan perhitungan koefisien jalur, terlebih dahulu harus dilakukan analisis korelasi dan regresi tiap dua variabel.

Penelitian ini untuk mengkaji atau menganalisis pengaruh satu variabel terhadap variabel yang lain. Variabel yang dikaji terdiri dari empat, yaitu: (1) Kinerja Karyawan; (2) Kecerdasan Emosional; (3) Motivasi Kerja; (4) Sikap Kerja.

Populasi penelitian adalah karyawan staff PT Ithaca Resources Departemen Accounting. Dalam penelitian ini sampel terdiri dari sebagian jumlah karyawan staff PT Ithaca Resources departemen accounting. Teknis pengambilan sampel ditempuh dengan cara: (1) menetapkan jumlah kerangka sampel, yaitu karyawan staf departemen accounting, (2) mengambil sampel dengan teknik cara acak sederhana (Simple Random Sampling). Teknik ini digunakan untuk mengambil sampel sejumlah 90 responden dari jumlah kerangka sampel sebanyak 120 karyawan staff departemen accounting di PT Ithaca Resources. Teknik pengumpulan data dilakukan dengan menggunakan kuesioner dan tes. Pengukuran data yang ada dalam kuesioner dengan menggunakan skala lima. Instrumen dikembangkan melalui indikator kajian teoritis variabel-variabel Kinerja Karyawan, Kecerdasan Emosional, Motivasi Kerja, Sikap Kerja.

Skala penilaian untuk variabel Kinerja Karyawan, Kecerdasan Emosional, Motivasi Kerja, dan Sikap Kerja memiliki lima kategori pilihan jawaban, yaitu: (1) Sangat Sering, (2) Sering, (3) Cukup Sering, (4) Jarang, dan (5) Tidak pernah.

Instrumen diuji terlebih dahulu sebelum dipergunakan dalam penelitian. Pengujian instrumen tersebut meliputi uji validitas dan reliabilitas. Dari hasil pengujian tersebut diperoleh butir-butir instrumen yang valid dan tidak valid (drop). Instrumen yang tidak valid dibuang atau tidak dipergunakan dalam penelitian. 


\section{HASIL DAN PEMBAHASAN}

Model Struktural dan Matriks Korelasi Antar-variabel. Model struktural dalam analisis pengaruh kecerdasan emosional $\left(\mathrm{X}_{1}\right)$, motivasi kerja $\left(\mathrm{X}_{2}\right)$, dan sikap kerja $\left(\mathrm{X}_{3}\right)$ terhadap kinerja karyawan (Y). Model struktural tersebut disajikan pada Gambar 2. Matrik korelasi antar variabel dalam model struktural sebagaimana disajikan pada Gambar 2, dapat dilihat pada Tabel 1. Dalam Tabel tersebut dapat dilihat bahwa seluruh nilai koefisien korelasi antarvariabel bertanda positif. Hal ini menunjukkan bahwa terdapat hubungan positif antar variabel yang terdapat dalam model struktural. Di samping itu, seluruh nilai koefisien korelasi tersebut signifikan pada $\alpha=0,05$

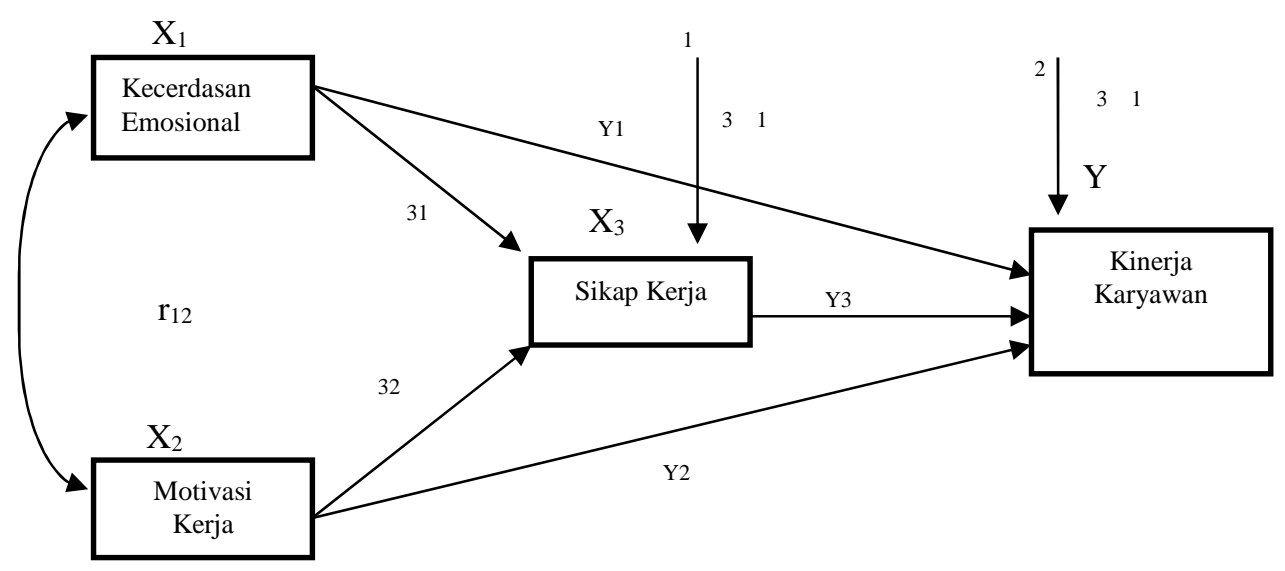

Gambar 2. Model Struktural dan Matrik Korelasi Antar Variabel

Tabel 1. Matriks Koefisien Korelasi sederhana antar variabel

\begin{tabular}{ccccc}
\hline Variabel & $\mathrm{X}_{1}$ & $\mathrm{X}_{2}$ & $\mathrm{X}_{3}$ & $\mathrm{Y}$ \\
\hline $\mathrm{X}_{1}$ & 1,000 & & & \\
$\mathrm{X}_{2}$ & 0,591 & 1,000 & & \\
$\mathrm{X}_{3}$ & 0,665 & 0,775 & 1,000 & \\
$\mathrm{Y}$ & 0,546 & 0,817 & 0,651 & 1,000 \\
\hline
\end{tabular}

Keterangan:

Seluruh nilai koefisien korelasi signifikan pada $\alpha=0,05$.

Model Hubungan kausal Antar Variabel pada Substruktur-1. Bagan model hubungan kausal antar variabel pada substruktur -1 antar variabel pada substruktur-1 adalah hubungan kausal empiris variabel $\mathrm{X}_{1}$ dan $\mathrm{X}_{2}$ ke $\mathrm{X}_{3}$. 


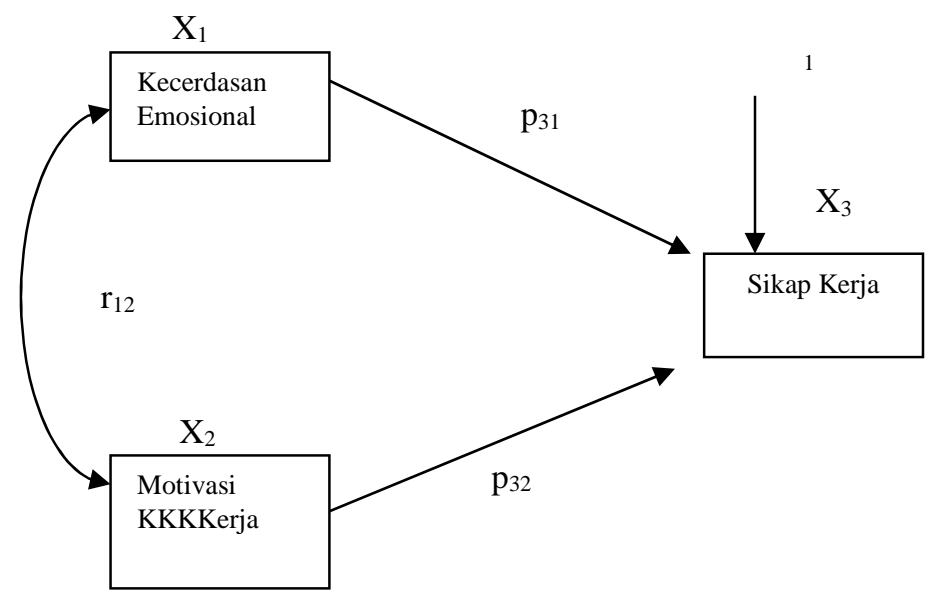

Gambar 3. Hubungan Kausal pada Substruktur-1

Keterngan: $\quad \varepsilon_{1}=$ Pengaruh variabel lain pada substruktur-1

Hubungan kausal antar variabel pada substruktur-1 terdiri atas sebuah variabel endogen, yaitu $X_{3}$ dan dua variabel eksogen, yaitu $X_{1}$, dan $X_{2}$. Matrik korelasi antarvariabel eksogen pada substruktur-1 dapat dilihat pada Tabel berikut.

Tabel 2. Matriks Korelasi Antarvariabel Eksogen pada Substruktur-1

\begin{tabular}{ccc}
\hline variabel & $X_{1}$ & $X_{2}$ \\
\hline$X_{1}$ & 1 & 0,591 \\
$X_{2}$ & 0,591 & 1 \\
\hline
\end{tabular}

Berdasarkan matrik korelasi antarvariabel eksogen, sebagaimana disajikan pada Tabel 2 selanjutnya ditentukan matriks invers korelasi. Penentuan matriks invers korelasi antarvariabel eksogen pada substruktur-1 dilakukan dengan menggunakan fasilitas matematika pada Microsoft Excel. Hasil penentuan matriks invers korelasi antarvariabel eksogen tersebut dapat dilihat pada Tabel 3.

Tabel 3. Matriks Invers Korelasi Antarvariabel Eksogen pada Substruktur-1

\begin{tabular}{ccc}
\hline variabel & $\mathbf{X}_{\mathbf{1}}$ & $\mathbf{X}_{\mathbf{2}}$ \\
\hline $\mathrm{X}_{1}$ & 1,536762 & $-0,90823$ \\
$\mathrm{X}_{2}$ & $-0,90823$ & 1,53676 \\
\hline
\end{tabular}

Setelah diperoleh matriks korelasi dan matriks invers korelasi antarvariabel eksogen pada substruktur-1, selanjutnya dapat dilakukan perhitungan masing-masing koefisien jalur $\rho_{\mathrm{ji}}$. Hasil perhitungan koefisien jalur pada substruktur-1 disajikan pada Tabel 4. 
Tabel 4. Koefisien Jalur pada Substruktur-1

\begin{tabular}{lll}
\hline No. & Jalur & Koefisien Jalur \\
\hline 1. & $\mathrm{X}_{3}-\mathrm{X}_{1}$ & $\mathrm{p}_{31}=0,554$ \\
2. & $\mathrm{X}_{3-} \mathrm{X}_{2}$ & $\mathrm{p}_{32}=0,443$ \\
\hline
\end{tabular}

Hasil perhitungan uji $\mathrm{t}$ disajikan pada Tabel 5, dapat dilihat bahwa nilai $\mathrm{t}$ hitung pada substruktur-1 lebih besar dari $\mathrm{t}$ tabel $\left.=\mathrm{t}_{(} \alpha=0,05 ; \mathrm{dk}=87\right)$, dengan demikian, koefisien jalur signifikan.

Tabel 5. Hasil Uji Individu Koefisien Jalur pada Substruktur-1

\begin{tabular}{lccccc}
\hline \multirow{2}{*}{ Jalur } & $\begin{array}{c}\text { Koefisien } \\
\text { Jalur }\end{array}$ & $\mathrm{dk}$ & $\mathrm{t}_{\text {hitung }}$ & $\mathrm{t}_{\text {tabel }}$ & \multirow{2}{*}{ Hasil Uji } \\
$\mathrm{X}_{3} \mathrm{X}_{1}$ & 0,554 & 87 & 4,969 & $\alpha=0,05$ & \\
$\mathrm{X}_{3} \mathrm{X}_{2}$ & 0,443 & 87 & 3,296 & 1,6628 & Signifikan \\
\hline
\end{tabular}

Koefisien Jalur pada Substruktur-2. Sebagaimana telah dikemukakan, model struktural pada Gambar 3 terdiri atas dua substruktur. Hasil perhitungan dan pengujian koefisien jalur pada substruktur-1 telah dipaparkan pada bagian terdahulu. Selanjutnya, hubungan kausal pada substruktur-2 disajikan pada Gambar 4.

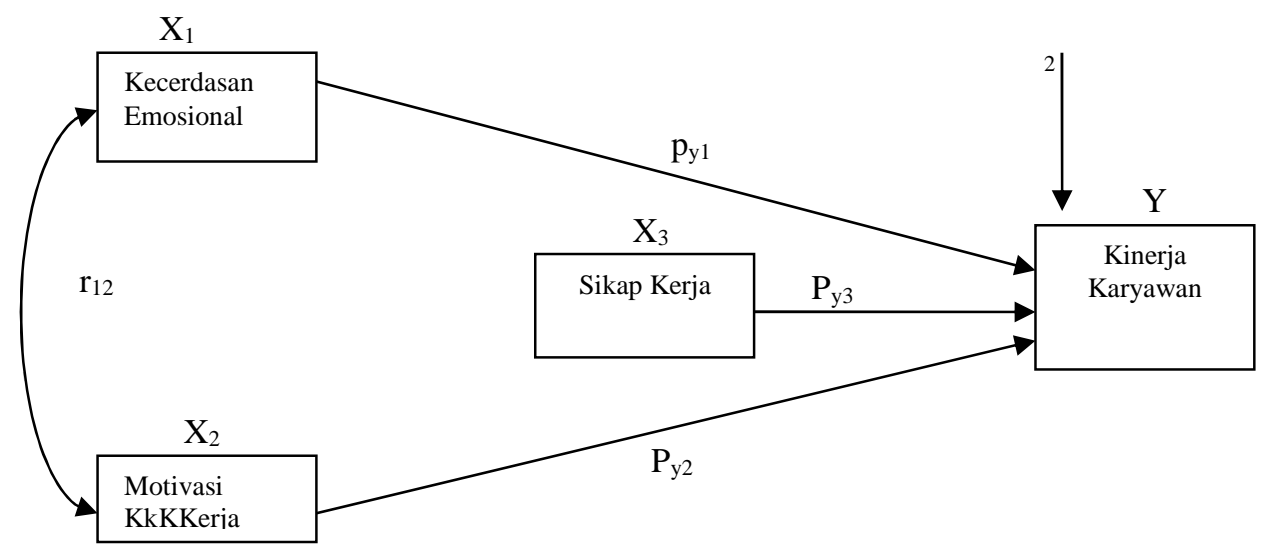

Gambar 4. Hubungan Kausal pada Substruktur-2

Hubungan kausal antarvariabel pada substruktur-2 terdiri atas sebuah variabel endogen, yaitu $\mathrm{Y}$ dan tiga variabel eksogen, yaitu $\mathrm{X}_{1}, \mathrm{X}_{2}$ dan $\mathrm{X}_{3}$. Matriks korelasi antarvariabel eksogen pada substruktur-2 dapat dilihat pada Tabel 6 .

Tabel 6. Matriks Korelasi Antar-variabel Eksogen pada Substruktur-2

\begin{tabular}{lccc}
\hline & $\mathrm{X}_{1}$ & $\mathrm{X}_{2}$ & $\mathrm{X}_{3}$ \\
\hline $\mathrm{X}_{1}$ & 1,000 & 0,591 & 0,665 \\
$\mathrm{X}_{2}$ & 0,591 & 1,000 & 0,775 \\
$\mathrm{X}_{3}$ & 0,665 & 0,775 & 1,000 \\
\hline
\end{tabular}


Berdasarkan matriks korelasi antar variabel eksogen, sebagaimana disajikan pada Tabel 6 selanjutnya ditentukan matriks invers korelasi. Penentuan matriks invers korelasi antar-variabel oksogen pada substruktur-1 dilakukan dengan menggunakan fasilitas matematika pada Microsoft Excel. Hasil penentuan matriks invers korelasi antar-variabel eksogen tersebut dapat dilihat pada Tabel 7.

Tabel 7. Matriks Invers Korelasi Antar-variabel Eksogen pada Substruktur-2

\begin{tabular}{cccc}
\hline & $\mathrm{X} 1$ & $\mathrm{X} 2$ & $\mathrm{X} 3$ \\
\hline $\mathrm{X} 1$ & 1,84008 & $-0,34843$ & $-0,95362$ \\
$\mathrm{X} 2$ & $-0,34843$ & 2,569891 & $-1,75996$ \\
$\mathrm{X} 3$ & $-0,95362$ & $-1,75996$ & 2,998121 \\
\hline
\end{tabular}

Setelah diperoleh matriks korelasi dan matriks invers korelasi antar-variabel eksogen pada substruktur-2, selanjutnya dapat dilakukan perhitungan masing-masing koefisien jalur $\rho_{\mathrm{ji}}$.. Hasil perhitungan koefisien jalur pada Substruktur-2 disajikan pada Tabel 8

Tabel 8. Koefisien Jalur pada Substruktur-2

\begin{tabular}{ccc}
\hline No. & Jalur & Koefisien Jalur \\
\hline 1. & $\mathrm{Y}-\mathrm{X}_{1}$ & $\mathrm{p}_{\mathrm{y} 1}=0,3723$ \\
2. & $\mathrm{Y}-\mathrm{X}_{2}$ & $\mathrm{p}_{\mathrm{y} 2}=0,2978$ \\
3. & $\mathrm{Y}-\mathrm{X}_{3}$ & $\mathrm{p}_{\mathrm{y} 3}=0,3297$ \\
\hline
\end{tabular}

Koefisien determinasi pada Substruktur-2, yaitu $\mathrm{R}^{2} \mathrm{Y,x1, \textrm {x } 2 , \mathrm { x } 3}=0,9947$. Hal ini berarti bahwa variasi perubahan variabel $X_{1}, X_{2}$ dan $X_{3}$ dapat menjelaskan 99,46\% variasi dalam variabel Kinerja Karyawan (Y). Pengaruh variabel lain terhadap variabel Y, yaitu $\rho_{4} \varepsilon_{2}=$ 0,0728. Hal ini menunjukkan bahwa selain ketiga variabel eksogen tersebut, terdapat variabel lain yang berpengaruh terhadap variabel Kinerja Karyawan (Y) dengan pengaruh sebesar $7,28 \%$.

Uji keseluruhan atau uji $\mathrm{F}$ terhadap koefisien jalur pada Substruktur-2 menghasilkan $F_{\text {hitung }}=27,1849$. Sementara, $F_{\text {table }}=F_{(\alpha=0,05 ; \mathrm{dk}=86)}$ pada substruktur- 2 sebesar 3,76. dan $F_{\text {table }}=F_{(\alpha=0,01 ; \mathrm{dk}=86)}$ pada substruktur-2 sebesar 4,13. Dengan demikian $F_{\text {hitung }}>F_{\text {tabel. }}$. Oleh karena itu, $\mathrm{H}_{0}: \rho_{41}=\rho_{42}=p_{43}=0$ ditolak. Hal ini berarti bahwa variasi variabel $\mathrm{X}_{1}, \mathrm{X}_{2}$, dan $\mathrm{X}_{3}$ secara bersama-sama dapat menjelaskan dengan baik variabel Y. Dengan demikian, dapat dilanjutkan pada uji individu atau uji t.

Hasil perhitungan uji t disajikan pada Tabel 9. Dapat dilihat bahwa nilai $\mathrm{t}$ hitung seluruh koefisien jalur pada Substruktur-2 lebih besar dari $\mathrm{t}$ tabel $=\mathrm{t}(\alpha=0,05 ; \mathrm{dk}=86)$. Dengan demikian dapat dikemukakan bahwa seluruh koefisien jalur pada Substruktur-2, yaitu $\rho_{41}$, $\rho_{42}$ dan $\rho_{43}$ adalah signifikan atau berbeda nyata dengan nol.

Tabel 9. Hasil Uji Individu Koefisien Jalur pada Substruktur-2

\begin{tabular}{|c|c|c|c|c|c|}
\hline Jalur & Koefisien Jalur & $\mathrm{dk}$ & t hitung & $\begin{array}{c}\mathrm{t} \text { tabel } \\
\alpha \alpha=0,05\end{array}$ & Hasil Uji \\
\hline $\mathrm{Y}-\mathrm{X}_{1}$ & 0,3723 & 87 & 2,3880 & 1,6628 & Signifikan \\
\hline $\mathrm{Y}-\mathrm{X}_{2}$ & 0,2978 & 87 & 4,2747 & 1,6628 & Signifikan \\
\hline $\mathrm{Y}-\mathrm{X}_{3}$ & 0,3298 & 87 & 2,3881 & 1,6628 & Signifikan \\
\hline
\end{tabular}


Berdasarkan hasil perhitungan analisis jalur pada Substruktur-1 dan Substruktur-2 diperoleh nilai-nilai koefisien jalur yang menunjukkan hubungan kausal dalam model struktural yang dianalisis sebagaimana disajikan pada Gambar 5.

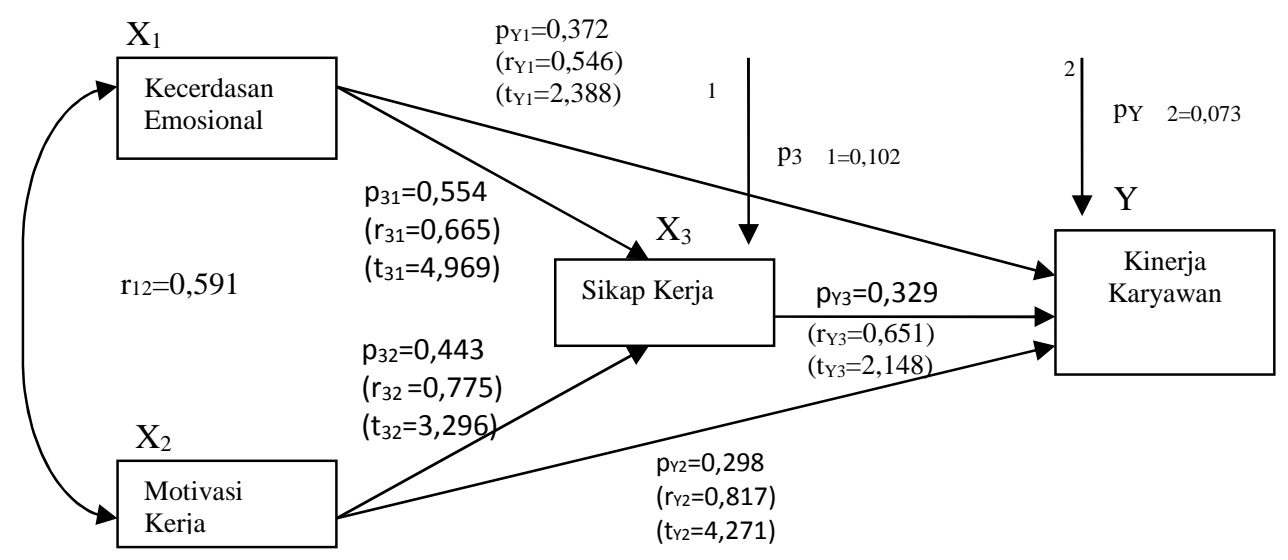

Gambar 5. Model Hubungan Struktural Antar-variabel berdasarkan hasil perhitungan Analisis Jalur

Keterangan: $\varepsilon_{1}=$ Pengaruh variabel lain pada substruktur $-1 ; \varepsilon_{2}=$ Pengaruh variabel lain pada substruktur-2

Sebagaimana telah dikemukakan, nilai-nilai koefisien jalur yang ditunjukkan oleh Gambar 5 di atas ternyata semuanya signifikan. Oleh karena itu, model struktural tidak perlu dilakukan modifikasi.

Pengujian Hipótesis. Setelah dilakukan analisis model struktural hubungan kausal, hasil perhitungan yang diperoleh digunakan untuk menguji hipotesis yang diajukan. Penarikan kesimpulan hipotesis dilakukan melalui perhitungan nilai koefisien jalur dan signifikansi untuk setiap jalur yang diteliti. Selanjutnya nilai koefisien setiap jalurnya berdasarkan hipotesis yang diajukan dapat diuraikan sebagai berikut:

Kecerdasan Emosional $\left(\mathbf{X}_{1}\right)$ berpengaruh langsung positif terhadap Kinerja Karyawan (Y). Untuk membuktikan bahwa kecerdasan emosional $\left(\mathrm{X}_{1}\right)$ berpengaruh positif terhadap kinerja karyawan (Y), hipotesis yang diuji adalah sebagai berikut:

$$
\begin{aligned}
& \mathrm{H}_{\mathrm{o}}: \beta_{\mathrm{Y} 1} \leq 0 \\
& \mathrm{H}_{1}: \beta_{\mathrm{Y} 1}>0
\end{aligned}
$$

Dari hasil perhitungan diperoleh nilai koefisien jalur $\left(\rho_{\mathrm{Y} 1}\right)=0,372$ dengan $\mathrm{t}$ hitung $=2,3881$ dan pada taraf nyata $\alpha=0,05$ diperoleh $\mathrm{t}_{\text {tabel }}=1,6628$. Karena nilai $\mathrm{t}$ hitung $>\mathrm{t}$ tabel, maka tolak $\mathrm{H}_{\mathrm{o}}, \mathrm{H}_{1}$ terima pada koefisien jalur sangat signifikan. Dari temuan ini dapat dikatakan bahwa kecerdasan emosional berpengaruh langsung positif terhadap kinerja karyawan.

Motivasi Kerja $\left(\mathrm{X}_{2}\right)$ berpengaruh langsung positif terhadap Kinerja karyawan (Y). Untuk membuktikan bahwa motivasi kerja $\left(\mathrm{X}_{2}\right)$ berpengaruh langsung positif terhadap kinerja karyawan $(\mathrm{Y})$, hipotesis yang diuji adalah sebagai berikut: 


$$
\begin{aligned}
& \mathrm{H}_{\mathrm{o}}: \beta_{\mathrm{Y} 2} \leq 0 \\
& \mathrm{H}_{\mathrm{O}}: \beta_{\mathrm{Y} 2}>0
\end{aligned}
$$

Dari hasil perhitungan diperoleh nilai koefisien jalur $\left(\rho_{Y 2}\right)=0,298$ dengan $t$ hitung $=$ 4,2714 dan pada taraf nyata $\alpha=0,05$ diperoleh $t_{\text {tabel }}=1,6628$. Karena nilai $t_{\text {hitung }}>\mathrm{t}_{\text {tabel, }}$, maka tolak $\mathrm{H}_{\mathrm{o}}, \mathrm{H}_{1}$ pada koefisien jalur sangat signifikan. Dari temuan ini dapat dikatakan bahwa motivasi kerja berpengaruh langsung positif terhadap kinerja karyawan .

Sikap Kerja ( $\left.\mathrm{X}_{3}\right)$ berpengaruh langsung positif terhadap Kinerja karyawan (Y). Untuk membuktikan bahwa sikap kerja $\left(\mathrm{X}_{3}\right)$ berpengaruh langsung positif terhadap kinerja karyawan (Y), hipotesis yang diuji adalah sebagai berikut:

$$
\begin{aligned}
& \mathrm{H}_{\mathrm{o}}: \beta_{\mathrm{Y} 3} \leq 0 \\
& \mathrm{H}_{1}: \beta_{\mathrm{Y} 3}>0
\end{aligned}
$$

Dari hasil perhitungan diperoleh nilai koefisien jalur $\left(\rho_{\mathrm{Y} 3}\right)=0,329$ dengan $\mathrm{t}_{\text {hitung }}=$ 2,1482 dan pada taraf nyata $\alpha=0,05$ diperoleh $t$ tabel $=1,6628$. Karena nilai $t$ hitung $>t$ tabel, maka koefisien jalur sangat signifikan. Dari temuan ini dapat dikatakan bahwa motivasi kerja berpengaruh positif terhadap pengambilan keputusan individual.

Kecerdasan Emosional $\left(X_{1}\right)$ berpengaruh langsung positif terhadap Sikap Kerja (X). Untuk membuktikan bahwa kecerdasan emosional $\left(\mathrm{X}_{1}\right)$ berpengaruh langsung positif terhadap sikap kerja $\left(\mathrm{X}_{3}\right)$, hipotesis yang diuji adalah sebagai berikut:

$$
\begin{aligned}
& H_{0}: \beta_{31} \leq 0 \\
& H_{1}: \beta_{31}>0
\end{aligned}
$$

Dari hasil perhitungan diperoleh nilai koefisien jalur $\left(\rho_{31}\right)=0,554$ dengan $t$ hitung $=$ 4,9691 dan pada taraf nyata $\alpha=0,05$ diperoleh $t_{\text {tabel }}=1,6628$. Karena nilai $t_{\text {hitung }}>\mathrm{t}_{\text {tabel }}$, maka koefisien jalur sangat signifikan. Dari temuan ini dapat dikatakan bahwa kecerdasan emosional berpengaruh langsung positif terhadap sikap kerja.

Motivasi Kerja $\left(\mathbf{X}_{2}\right)$ berpengaruh langsung positif terhadap Sikap Kerja $\left(\mathbf{X}_{3}\right)$. Untuk membuktikan bahwa motivasi kerja $\left(\mathrm{X}_{2}\right)$ berpengaruh langsung positif terhadap sikap kerja $\left(\mathrm{X}_{3}\right)$, hipotesis yang diuji adalah sebagai berikut:

$$
\begin{aligned}
& \mathrm{H}_{\mathrm{o}}: \beta_{32} \leq 0 \\
& \mathrm{H}_{1}: \beta_{32}>0
\end{aligned}
$$

Dari hasil perhitungan diperoleh nilai koefisien jalur $\left(\rho_{32}\right)=0.443$ dengan $t$ hitung $=$ 3,2962 dan pada taraf nyata $\alpha=0,05$ diperoleh $t$ tabel $=1,6628$. Karena nilai $t$ hitung $>t_{\text {tabel }}$, maka koefisien jalur signifikan. Dari temuan ini dapat dikatakan bahwa motivasi kerja berpengaruh langsung positif terhadap sikap kerja. Setelah hasil analisis dan uji statistik terhadap hipotesis, maka rangkuman hasil pengujian untuk setiap hipotesis dapat dilihat pada Tabel 10. 
Tabel 10. Rekapitulasi hasil pengujian hipótesis

\begin{tabular}{|c|c|c|c|c|}
\hline $\mathrm{No}$ & Hipotesis & Uji Statistik & Keputusan $\mathrm{H}_{\mathrm{o}}$ & Kesimpulan \\
\hline 1. & $\begin{array}{l}\text { Kecerdasan emosional }\left(\mathrm{X}_{1}\right) \\
\text { berpengaruh langsung positif } \\
\text { terhadap kinerja karyawan } \\
\text { (Y) }\end{array}$ & $\begin{array}{l}\mathrm{H}_{\mathrm{o}}: \beta_{\mathrm{Y} 1} \leq 0 \\
\mathrm{H}_{1}: \beta_{\mathrm{Y} 1}>0\end{array}$ & $\mathrm{H}_{\mathrm{o}}$ ditolak & $\begin{array}{l}\text { Mempunyai } \\
\text { pengaruh } \\
\text { langsung positif }\end{array}$ \\
\hline 2. & $\begin{array}{l}\text { Motivasi kerja }\left(\mathrm{X}_{2}\right) \\
\text { berpengaruh langsung positif } \\
\text { terhadap Kinerja karyawan } \\
\text { (Y) }\end{array}$ & $\begin{array}{l}\mathrm{H}_{\mathrm{o}}: \beta_{\mathrm{Y} 2} \leq 0 \\
\mathrm{H}_{1}: \beta_{\mathrm{Y} 2}>0\end{array}$ & $\mathrm{H}_{\mathrm{o}}$ ditolak & $\begin{array}{l}\text { Mempunyai } \\
\text { pengaruh } \\
\text { langsung positif }\end{array}$ \\
\hline 3. & $\begin{array}{l}\text { Sikap kerja }\left(\mathrm{X}_{3}\right) \text { berpengaruh } \\
\text { langsung positif terhadap } \\
\text { kinerja karyawan }(\mathrm{Y})\end{array}$ & $\begin{array}{l}\mathrm{H}_{\mathrm{o}}: \beta_{\mathrm{Y} 3} \leq 0 \\
\mathrm{H}_{1}: \beta_{\mathrm{Y} 3}>0\end{array}$ & $\mathrm{H}_{\mathrm{o}}$ ditolak & $\begin{array}{l}\text { Mempunyai } \\
\text { pengaruh } \\
\text { langsung positif }\end{array}$ \\
\hline
\end{tabular}

Berdasarkan analisa data dan perhitungan statistik dalam pengujian hipotesis, telah membuktikan bahwa lima hipotesis yang diajukan diterima kebenarannya. Berkait dengan hasil pembuktian hipotesis tersebut, pada bagian ini secara berturut-turut akan diuraikan pembahasan hasil penelitian sebagai berikut:

Kecerdasan Emosional berpengaruh langsung positif terhadap Kinerja Karyawan. Hasil temuan penelitian menunjukan bahwa hipotesis pertama diterima kebenarannya, dengan demikian kecerdasan emosional berpengaruh langsung positif terhadap kinerja karyawan. Artinya, apabila kecerdasan emosional tinggi maka akan meningkatkan kemampuan kinerja karyawan. Besarnya kontribusi secara langsung variabel kecerdasan emosional terhadap variabel kinerja karyawan dengan nilai koefisien jalur sebesar 0,372. Oleh karena itu, untuk mengoptimalkan kinerja karyawan yang rasional maka harus diupayakan dengan meningkatkan kecerdasan emosional. Selanjutnya dapat dikatakan bahwa karyawan yang memiliki kecerdasan emosional tinggi cenderung memiliki kinerja karyawan yang kualitas tinggi dan karyawan yang miliki kecerdasan emasional rendah cenderung miliki kemampuan kinerja karyawan rendah. Sehingga dapat dikatakan kecerdasan emosional berpengaruh langsung positif terhadap pengambilan keputusan individu.

Motivasi Kerja berpengaruh langsung positif terhadap Kinerja Karyawan. Dari penelitian menunjukan besarnya kontribusi variabel motivasi kerja secara langsung terhadap variabel kinerja karyawan dengan nilai koefisien jalur sebesar 0,298. Oleh karena itu, untuk mengoptimalkan kinerja karyawan harus diupayakan meningkatkan motivasi kerja, Sehingga dapat dikatakan bahwa sikap kerja berpengaruh langsung positif terhadap kinerja karyawan.

Sikap Kerja berpengaruh langsung positif terhadap Kinerja karyawan. Hasil temuan penelitian menunjukkan bahwa hipotesis ketiga diterima kebenarannya, dengan demikian sikap kerja berpengaruh langsung positif terhadap kinerja karyawan. Sehingga karyawan yang memiliki sikap kerja tinggi maka akan memiliki kemampuan kinerja karyawan secara rasional tinggi pula, sebaliknya pegawai yang memiliki sikap kerja negatif maka kinerja karyawa secara rasional rendah. 
Besarnya kontribusi variabel kecerdasan emosional secara langsung berkontribusi terhadap kinerja karyawan dengan nilai koefisien jalur sebesar 0,329. Oleh karena itu, untuk mengoptimalkan kinerja karyawan harus diupayakan meningkatkan kecerdasan emosional, sehingga dapat dikatakan bahwa motivasi berpengaruh langsung positif terhadap pengambilan keputusan individual.

\section{Kecerdasan Emosional berpengaruh langsung positif terhadap Sikap Kerja karyawan. Mengacu pada hasil penelitian menunjukan besarnya kontribusi variabel kecerdasan emosional berpengaruh langsung positif terhadap motivasi kerja dengan nilai koefisien jalur sebesar 0,554. Oleh karena itu, untuk mengoptimalkan kinerja karyawan harus diupayakan meningkatkan kecerdasan emosional, Sehingga dapat dikatakan bahwa kecerdasan emosional berpengaruh langsung positif terhadap motivasi kerja.}

Motivasi Kerja berpengaruh langsung positif terhadap Sikap Kerja karyawan. Hasil Temuanhasil temuan menunjukan besarnya kontribusi variabel motivasi kerja berpengaruh langsung positif terhadap variabel sikap kerja dengan nilai koefisien jalur sebesar 0,443. Oleh karena itu, untuk mengoptimalkan kinerja karyawan harus diupayakan meningkatkan motivasi kerja, Sehingga dapat dikatakan bahwa motivasi kerja berpengaruh langsung positif terhadap sikap kerja.

\section{PENUTUP}

Simpulan. Berdasarkan hasil analisis data penelitian dan pembahasan pada bab sebelumnya tentang faktor-faktor yang memengaruhi kinerja karyawan, maka hasil penelitian dapat disimpulkan sebagai berikut: (1) Kecerdasan emosional berpengaruh langsung positif terhadap kinerja karyawan. Artinya apabila kecerdasan emosional meningkat menyebabkan peningkatan kualitas kinerja karyawan; (2) Sikap kerja berpengaruh langsung positif terhadap kinerja karyawan. Artinya apabila sikap kerja meningkat menyebabkan peningkatan kualitas kinerja karyawan; (3) Motivasi kerja berpengaruh langsung positif terhadap kinerja karyawan. Artinya apabila motivasi kerja meningkat menyababkan peningkatan kualitas kinerja karyawan; (4) Kecerdasan emosional berpengaruh langsung positif terhadap motivasi kerja karyawan. Artinya apabila kecerdasan emosional meningkat menyebabkan peningkatan kualitas motivasi kerja karyawan; (5) Sikap kerja berpengaruh langsung positif terhadap motivasi kerja karyawan. Artinya apabila sikap kerja meningkat menyebabkan peningkatan kualitas motivasi kerja karyawan.

Implikasi. Berdasarkan kesimpulan di atas, penelitian ini memberikan implikasi sebagai berikut: (1) Peningkatan kualitas kecerdasan emosional berimplikasi terhadap kinerja karyawan di PT Ithaca Resources; (2) Peningkatan kualitas motivasi kerja berimplikasi terhadap kinerja karyawan di PT Ithaca Resources; (3) Peningkatan kualitas sikap kerja berimplikasi terhadap kinerja karyawan di PT Ithaca Resources; (4) Peningkatan kualitas kecerdasan emosional berimplikasi terhadap kinerja karyawan melalui sikap kerja karyawan di PT Ithaca Resources; (5) Peningkatan kualitas motivasi kerja berimplikasi terhadap kinerja karyawan melalui sikap kerja karyawan di PT Ithaca Resources. 
Saran. Berdasarkan kesimpulan dan implikasi di atas, dapat dikemukakan beberapa saran dalam peningkatan kualitas kinerja karyawan di PT Ithaca Resources sebagai berikut: (1) Hendaknya setiap karyawan meningkatkan kemampuan kinerja karyawan melalui meningkatkan kecerdasan emosional, motivasi kerja, dan sikap kerja; (2) Hendaknya setiap karyawan diberi pelatihan untuk peningkatan kemampuan kinerja karyawan; (3) Hendaknya para pimpinan mendorong karyawan untuk dapat meningkatkan kualitas kinerja karyawan; (4) Hendaknya dalam mempromosikan karyawan dengan mempertimbangkan foktor-foktor kecerdasan emosional, motivasi kerja, dan sikap kerja. Sehingga karyawan akan mempunyai kemampuan dalam meningkatkan kinerja karyawan; (5) Hendaknya dalam melaksanakan rekrutmen karyawan sebaiknya memperhatikan faktor-faktor kecerdasan emosional, motivasi kerja, dan sikap kerja. Sehingga mempuanyai kemampuan dalam meningkatkan kinerja karyawan; (6) Hendaknya para peneliti bidang sumber daya manusia dapat menggunakan hasil penelitian ini untuk mengkaji secara komprehensif terhadap kinerja karyawan, karena masih ada foktor-foktor lain yang berpengaruh terhadap kinerja karyawan.

\section{DAFTAR RUJUKAN}

Adi W. A, (2008) “Analisis Stress dan Pengaruhnya terhadap Kinerja Pengusah Kecil”, Jurnal Kognisi Majalah Ilmiah Psikologi, Vol, 4, (4), hal 10-19

Amstrong, Michael, (2005) How to be an even Better Manager: a Complete A-Z, Great, Britain: Kogan Page Publishers.

Angelo Kinichi, Robert Kreitner, (2008) Organizational Behavior, key conceps, skills \& best practices, Boston: McGraw Hill.

Anderson, Neil, (2001) Handbook of Industrial, Work and Organizational Psychology, Personnel, London, Sage Publication.

Bacal, Robert, (2001) Performance Management, Terjemahan Surya Darma dan Yanuar Irawan, Jakarta: PT Gramedia Pustaka Utama.

Bambang Guritno dan Waridin, (2005) "Pengaruh Persepsi Karyawan Mengenai Perilaku Kepemimpinan, Kepuasan Kerja dan Motivasi Terhadap Kinerja”, JRBI, Vol 1. (1).

Colquitt, Jason A. Jeffery A. Lepine and Michael J Wesson, (2009) Organizational Behavior, New York: McGraw Hill.

David Harvey and Robert B Brown, (1996) Human Resources Management, An Emperimental Approach, (New Jersey, Printice-Hall International Inc.

Dale, A Timple, (2003) The Art of HRD, Developing Management Skills, Meningkatkan Ketrampilan Manajemen, Edisi Bahasa Indonesia, Jakarta, PT Bhuana Ilmu Populer.

Fred Luthans, (2008) Organizatinal Behavior Eleventh Edition, New York, McGraw-Hill.

Hersey and Blanchard, (2009) Organizational Behaviour, twelve edition, New Jersey:Pearson Education.

Jennifer M, geoge and Gareth R. Jones, (1978) Understanding and Managing Organizational Behavior, New York: Harcourt Brace.

John M. Ivancevich, Robert Konopaske, and Michael T. Matteson, (2005) Organizational Behavior and Management, $7^{\text {th }}$ Edition, Boston: McGraw Hill, Hill.

James L. Bowditch, Anthony F. Buono, (1997) A Primer on Organizational Behavior Fourth Edition, New York: John Wiley \& Sons, Inc. 
Junus, (2006) "Pengaruh Motivasi, Perilaku Pemimpin, dan Kesempatan Pengembangan Karier terhadap Kinerja Karyawan pada Dinas Pendapatan Daerah Kabupaten Pulau Buru", Jurnal Ekonomi Unmer, Vol. 8, (31), hal 501-516

Kreitner dan Kinicki, (2008) Organisational Behaviour, Five edition, New Jersey Pearsen Education.

Lisda Rahmasari, (2012) "Pengaruh Kecerdasan Intelektual, Kecerdasan Emosional dan Kecerdasan Spiritual terhadap Kinerja Karyawan", Jurnal Majalah Ilmiah Informatika, Vol. 03, (1), 1 Januari 2012

Mangkunegara, AA Anwar Prabu, (2005) Evaluasi Kinerja Sumber Daya Manusia, 1 Edition.

Mark Davis, (2006) Test EQ Anda, terjemahan Michael Wong, Suharsono, dan Siti Khotimah, Jakarta: Mitra Media.

Moh As"ad, (2003) Psikologi Industri, Yogyakarta: Liberty.

Martin J. Gannon, (1979) Oganization Behavior A Managerial and Organizationa Perspective; Canada: Little, Brown \& Company Limited.

Parlinda, Vera, (2008) "Pengaruh Kepemimpinan, Motivasi< Pelatihan dan Lingkungan Kerja pada Kinerja karyawan pada Perusahaan Daerah Air Minum Kota Surakarta", Jurnal STIE ,YKPN Yogjakarta, Vol. 17, (1), hal 79-92

Peni tanjungsari, (2011) "Pengaruh Stress Kerja terhadap Kepuasan Kerja Karyawan pada Kantor Pusat PT. Pos Indonesia (Persero) Bandung”, Jurnal Fakultas Ekonomi Universitas Komputer Indonesia, Vol. 2, (1), hal. 15

Prawirosentono, Suyadi, (2002) Kebijakan Kinerja Karyawan, Kiat Membangun Organisasi Kompetitig Menjelang Perdagangan Bebas Dunia, edisi 1, Yogyakarta.

Rivai Veithzal, (2003) Manajemen Sumber daya Manusia untuk Perusahaan, dari Teori Ke Praktik, Jakarta: PT. Raja Grafindo Persada.

Reni Hidayanti, (2008) "Kecerdasan Emosi, Stress Kerja terhadap Kinerja Karyawan", Jurnal Psikologi, Vol. 2, (1), hal. 17

Robert K. Cooper and Ayman Sawaf, (2001) Executive EQ: Emotional Intelligence in Leadership and Organizations, terjemahan Alex tri Kuntjono Widodo. Jakarta: PT. Gramedia Pustaka Utama.

Siti Fatimah Nurhayati, (2009) "Kontribusi Sumber Daya Manusia terhadap Kinerja Perusahaan”, Jurnal Masihkah diperlukan, Telaah Bisnis, Vol. 1, (1), hal. 25

Sonnentag, Sabine, (2002) Psychological Management of Individual Performance, New York, John Wiley \& Sons.

Stephen P. Robin, Timothy A. Judge, (2009) Organizational Behaviour, twelve ediition, New Jersey Pearsen, Education,

Steven Douglas Brown, Robert William Lent, (2005) Career Development and Counseling Putting Theory and Research to work, (New York, Wiley judge TA, Heller D \& Mount Mk.

Stephen P. Robbins, (2003) Essential of Organizational behavior, $7^{\text {th }}$ Edition, New Jersey: Pearson Education, Inc.,

Steven J. Stein, and Howard E. Book, Book, M.D., (2004) The EQ Edge: Emotional Intelligence and Your Success, Terjemahan Trinanda Rainy Januarsari, Yudhi Murtanto, Bandung: Kaifa,

Stephen P. Robbins, (2003) Organisational Behaviour, Terjemahan Benyamin Molan Jakarta; PT Indeks. 
Theresia, Sunarni dan Veni Istanti, (2007) "Pengaruh Stres kerja dan Motivasi Kerja terhadap Kinerja Karyawan di PT Interbis Sejahtera", Jurnal Teknik Industri, Vol. 7, (2), hal. 105

Triana Fitriastuti, (2013) "Pengaruh Kecerdasan Emosional, Komitmen Organisasional dan Organizational Citizenship Behavior terhadap Kinerja Karyawan di Dinas Perindustrian dan Perdagangan Kabupaten Kutai Timur", Jurnal Dinamika Manajemen, Vol.01, (1), hal. 10

T.R. Mitchell, (1997) "Matching Motivational Strategies with Organizational Contexts", in L.L. Cummings and B.M. Staw eds, Research in Organizational Behavior, vol 19 Greenwich, CT: JAI Press.

Yuningsih, (2009) "Membangun Komitmen dan Menciptakan Kinerja Sumber Daya Manusia untuk memperoleh keberhasilan Perusahaan", Jurnal Fokus Ekonomi, Vol. 1, (1), hal 111 